\title{
Training Program in the Construction projects
}

\author{
Suha Falih, Sawsan Rasheed Mohammed
}

\begin{abstract}
Construction is questionably a main part in relative to comprehensive development. It plays an important part in the role in the economy as and in people's survives over influencing and preserving the environment of the city-region's constructed, and it is a rising sector. To provide an efficient performance and more development of the economic, there is emphases on optimizing the employees contribution to the goals and areas of the governments. The training significance as a management central part has long been documented by principal writers.This paper aim to find the impact of training in the construction industry and how the training is been underestimate lead in increase the cost by using the simulation technique system dynamic. The research methodology include designing of questionnaire that consist of three items, the first item include, general Training (Training Program), evaluation of on-the-job training and evaluation of training after establishing work and the second part include building the model using system dynamic to show the effect of training on the cost of construction. the results the authors made the following conclusions.The absence of training program has very strong effect as the absence of such program is caused by the finance absence, this is common problem with Iraqi construction industry. The most environment of the Iraqi industry is the absence of the finance from both owner and contractor as they ignore this part and consider unnecessary expenses and this will lead to unqualified engineering or worker in the wrong job .The absence of management mean that, usually the contractor and his staff are working without the supervise or represented from the owner side, which some time mean unskilled workers may be hired which lead to delay of the work and cost overruns .
\end{abstract}

Key Word: Training, System Dynamic , Construction Projects

\section{INTRODUCTION}

Construction is questionably a main part in relative to comprehensive development . It plays an important part in the role in the economy as and in people's survives over influencing and preserving the environment of the cityregion's constructed, and it is a rising sector.[1] The success of failure of providing the physical growth of the oner is with the hand of the project managers inside the restrictions of charge, timetable, feature and safety necessities. A Project Manager that has competence is energetic to project achievement, and numerous lessons have emphasized serious skill. The focus of the projects and organization success is made on ensuring that the managers of the project obtain the core capabilities compulsory to be effective in their projects.

Revised Manuscript Received on May 15, 2020.

* Correspondence Author

Suha Falih*, Phd student. Civil Engineering Department, University of Baghdad/Baghdad. Iraq.

Sawsan Rasheed Mohammed, Prof. Civil Engineering Department, University of Baghdad/Baghdad.

(C) The Authors. Published by Blue Eyes Intelligence Engineering and Sciences Publication (BEIESP). This is an open access article under the CC BY-NC-ND license (http://creativecommons.org/licenses/by-nc-nd/4.0/)
[2] To provide an efficient performance and more development of the economic, there is emphases on optimizing the employees contribution to the goals and areas of the governments. The training significance as a management central part has long been documented by principal writers. For example according to Drucker (1998), the one influence a manager is exclusively predictable to mark is to give others idea and capability to achieve[3]

The development of the construction industry and ability to procure and innovative delivery, is determined by participation of highly well-informed and expert managers of the site. one of the main process in the construction industry is training to support organizations' encounter the site managers need with these qualities.[4]

Construction problems connected to and the workforce of the construction is diverse and periodic. Abdul Aziz et al (2008) annotation that the construction quality issues are a ongoing issue. Likewise, Sambasivan and Wen Soon (2006) detect that delay issues are periodic. MBAM (2010) emphasizes that the performance bury alia issues , overruns of cost and time and quality lacks, and those that connected to the workforce of the construction has directed to economy leak. This has caused in the earnings by foreign labour deportation and various resultant social and health harms, numerous main catastrophes, and the low output of the construction industry.[5]

Ineffective training of the manpower in the work force construction industry, in both amounts and necessary skills, has offered ongoing issues for Indonesian industry companies and clients for several years (Alwi et al. 2001).This paper aim to find the impact of training in the construction industry and how the training is been underestimate lead in increase the cost by using the simulation technique system dynamic.

\section{RESEARCH METHODOLOGY}

The research methodology include designing of questionnaire that consist of three items, the first item include , general Training (Training Program), evaluation of on-the-job training and evaluation of training after establishing work, the results of questionnaire used the Lickert scale as follow: 


\begin{tabular}{|c|c|c|c|c|}
\hline Five scale & \multicolumn{2}{|c|}{$\begin{array}{l}\text { Strongly } \\
\text { Disagree }\end{array}$} & Neutral Agree & \multirow[t]{2}{*}{$\begin{array}{l}\text { Strongly } \\
\text { Agree }\end{array}$} \\
\hline \multicolumn{4}{|c|}{ Q1: How training needs are identified in your organization } & \\
\hline Items & Mean & Std. Deviation & Evolution & \\
\hline $\begin{array}{l}\text { By performance review appraisal } \\
\text { of individual }\end{array}$ & 3.2432 & 1.55287 & Agree & \\
\hline $\begin{array}{l}\text { Through assessment center of } \\
\text { Through individuals target group } \\
\text { request }\end{array}$ & 3.1622 & 1.64170 & Agree & \\
\hline $\begin{array}{l}\text { Through internal survey } \\
\text { questionnaire }\end{array}$ & 2.8108 & 1.43058 & Agree & \\
\hline Through upcoming updating methods & 3.0541 & 1.56251 & Agree & \\
\hline
\end{tabular}

Q2: What kind of training methods are being followed in your organization?

\begin{tabular}{lll}
\hline On site & 2.0270 & .89711 \\
\hline
\end{tabular}

Q3: What are the barriers for conducting training in your organization. Give your opinion:-

\begin{tabular}{|c|c|c|c|c|}
\hline \multirow{3}{*}{$\begin{array}{l}\text { Items } \\
\text { No-management } \\
\text { initiation }\end{array}$} & $\mathrm{N}$ & Mean & Std. Deviation & \multirow{3}{*}{$\begin{array}{l}\text { Evolution } \\
\text { Agree }\end{array}$} \\
\hline & 37 & 2.6216 & 1.25502 & \\
\hline & & & & \\
\hline $\begin{array}{l}\text { non-availiblity of } \\
\text { funds }\end{array}$ & 37 & 3.9459 & 1.31119 & Agree \\
\hline $\begin{array}{l}\text { non-availiblity of } \\
\text { expert trainers in the } \\
\text { filed }\end{array}$ & 37 & 3.2703 & 1.34678 & Agree \\
\hline $\begin{array}{l}\text { poor understanding of } \\
\text { correct training } \\
\text { engineering system }\end{array}$ & 37 & 3.2432 & 1.34175 & Agree \\
\hline absence of training climate & 37 & 3.2703 & 1.38742 & Agree \\
\hline
\end{tabular}

Q 5:How does your organization evaluate individuals after imparting training?

\begin{tabular}{|c|c|c|c|}
\hline & Mean & Std. Deviation & Evolution \\
\hline Change in behavior & 3.4595 & 1.57400 & Agree \\
\hline $\begin{array}{l}\text { Change in functional } \\
\text { results }\end{array}$ & 2.7838 & 1.37710 & Agree \\
\hline $\begin{array}{l}\text { Improvement in } \\
\text { communication skills }\end{array}$ & 4.0811 & 1.01046 & Agree \\
\hline $\begin{array}{l}\text { Knowledge } \\
\text { enhancement }\end{array}$ & 3.5676 & 1.53732 & Agree \\
\hline
\end{tabular}


Q6: Please give your opinion on the following statement:

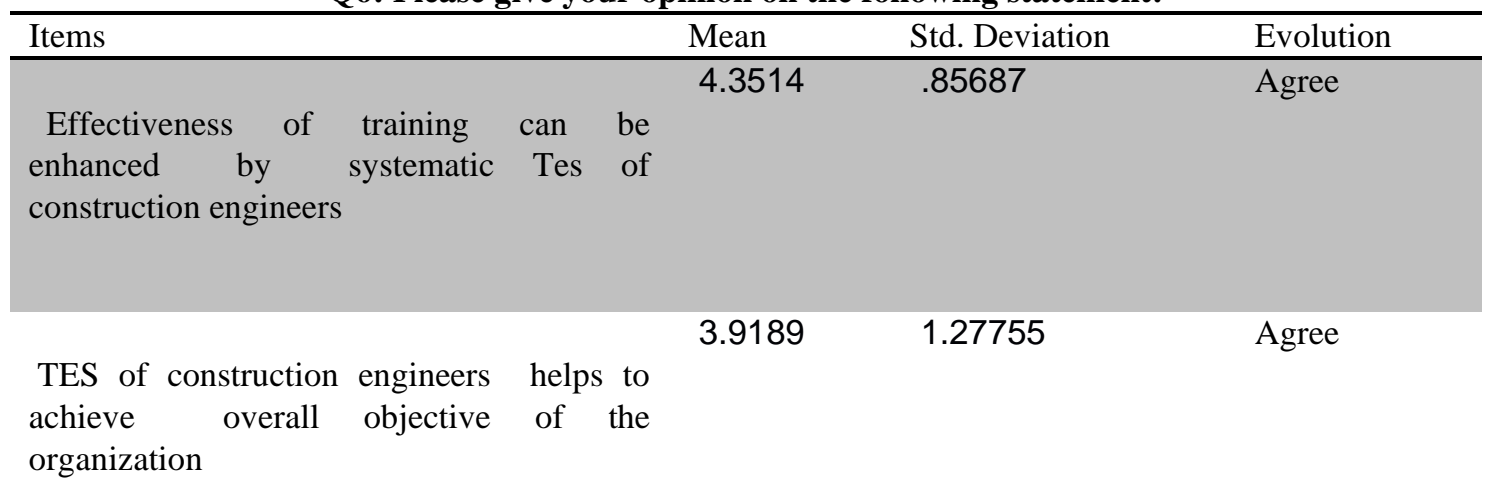

TES of construction engineers is useful for

$4.3243 \quad 1.05552 \quad$ Agree

the career development of individuals

Delay in construction projects can be minimised through TES

$4.4054 \quad 1.03975 \quad$ Agree

$\begin{array}{lccc}\begin{array}{l}\text { Work efficiency of construction engineers } \\ \text { can be improved through TES }\end{array} & 3.9459 & 1.31119 & \text { Agree } \\ & & & \\ \text { TES of construction engineers is useful } & 4.2162 & 1.05765 & \text { Agree }\end{array}$
for improving cost effectiveness while performing construction activities

$\begin{array}{llll}\text { TES can motivate construction engineers } & 5.5135 & 6.58965 & \text { strongly Agree } \\ \text { fora safe and environmental friendly job } & & \\ \text { execution } & & & \\ \text { TES of construction engineers can help } 4.1081 & 1.19684 & \text { Agree }\end{array}$
organization to adopt latest technologies and to keep the pace with time

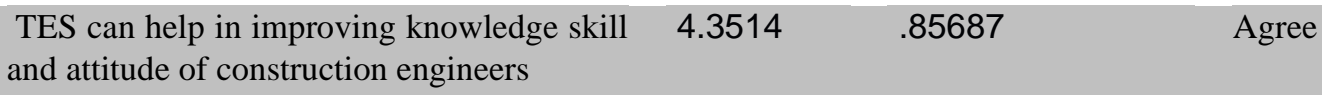

The second part include building the model using system dynamic to show the effect of training on the cost of construction , System dynamics is a methodology of dynamically complex systems studying and management simulation model building (Ford etl., 2002) System dynamics (SD) development was in the late of 1950s for industrial systems analysis (Forrester,1961). SD has been applied successfully to problems, ranging from social, environmental and industrial project management systems.

View of the world of an event-oriented or linear causal thinking cannot solve complicated problems adequately ( Sterman, 2000). Figure (3.10) shows the paradigm of the unidirectional thinking, that is grounded on the conjectural hypothesis which is the effect of collective of series causes or inputs that shape the outputs or events sequentially (Sterman, 2000). This kind of thinking tool that used for many problems, has the ability to show the variation of the current state and the state that desired or expected, then it can select and handled the problem by separating it from the environment that surrounds the problem.

the methodology as shown in the figure below 


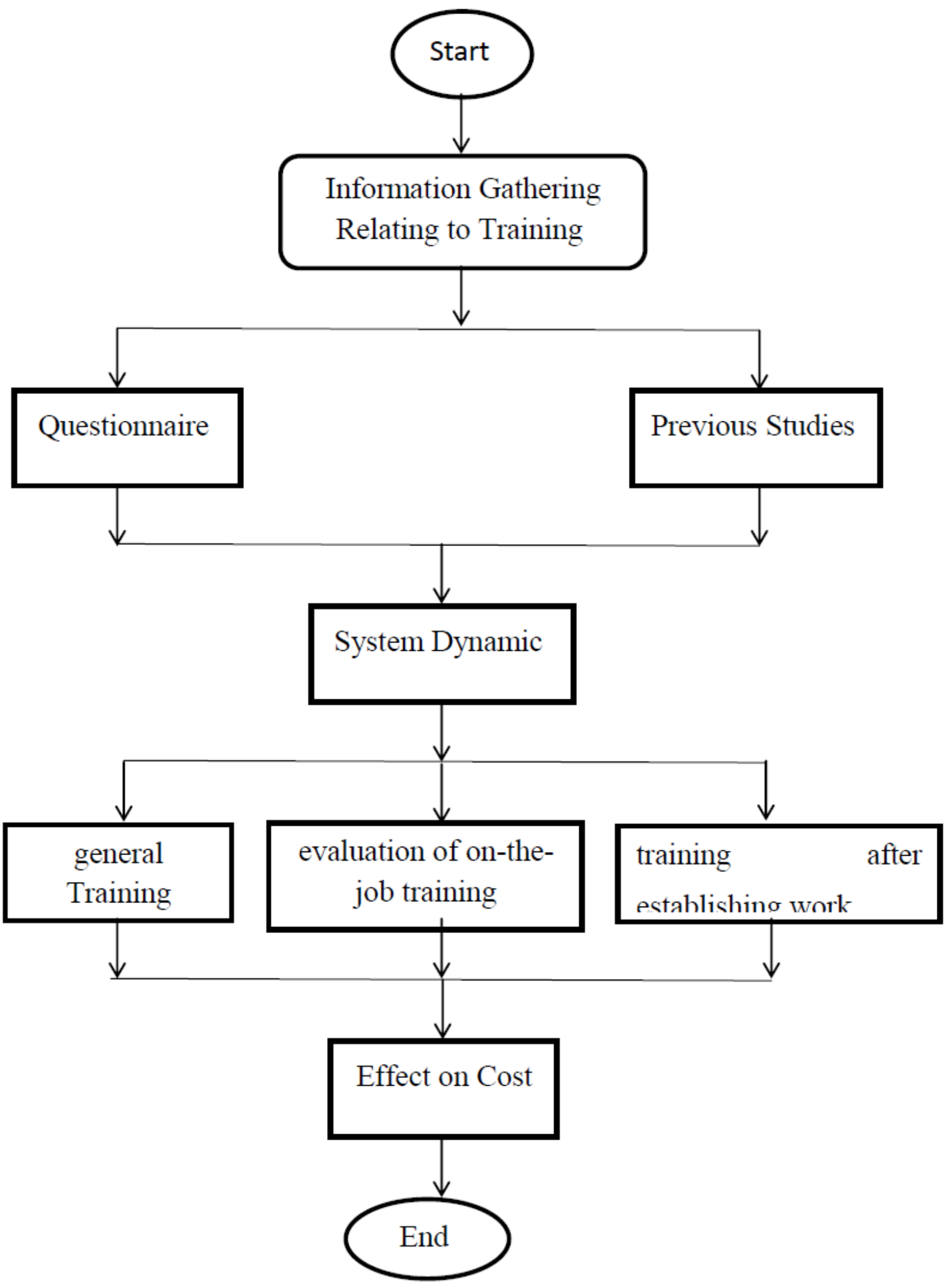

Figure (1) Flowchart of the Work

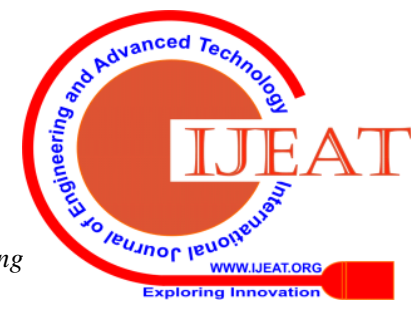




\section{RESULTS AND DISCUSSIONS}

The results of the system was first by taking the ideal project without any problem as shown below

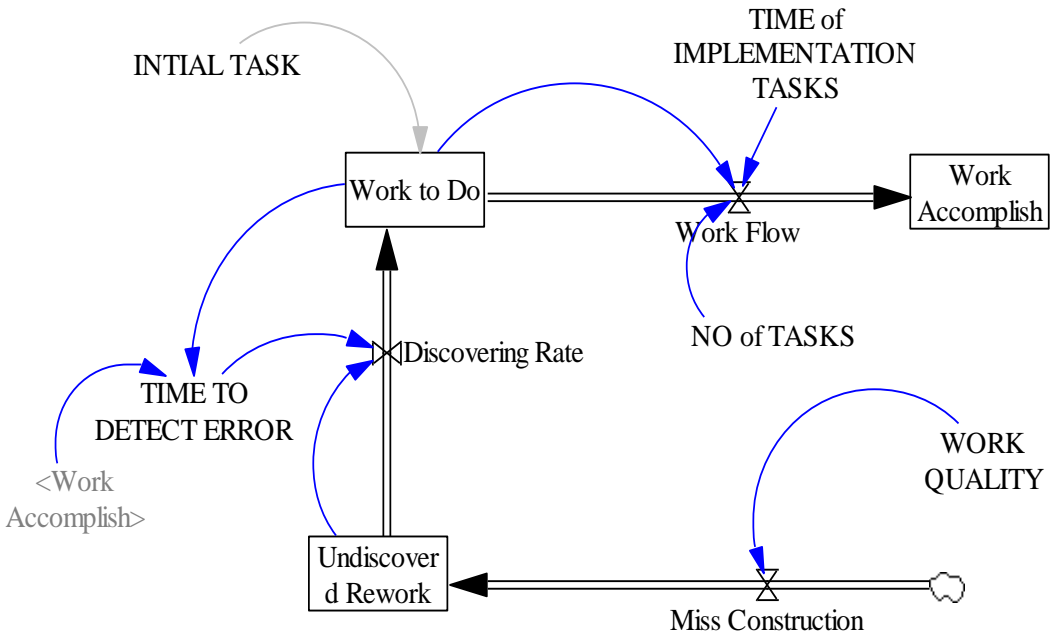

Figure (2) Ideal Project

The initial tasks is about 11 tasks that include the tasks that must be performed in the construction projects which from the earthworks to finishing and represent the work that must be accomplish.With time the work that actually performed is may be increased depending on the project conditions.

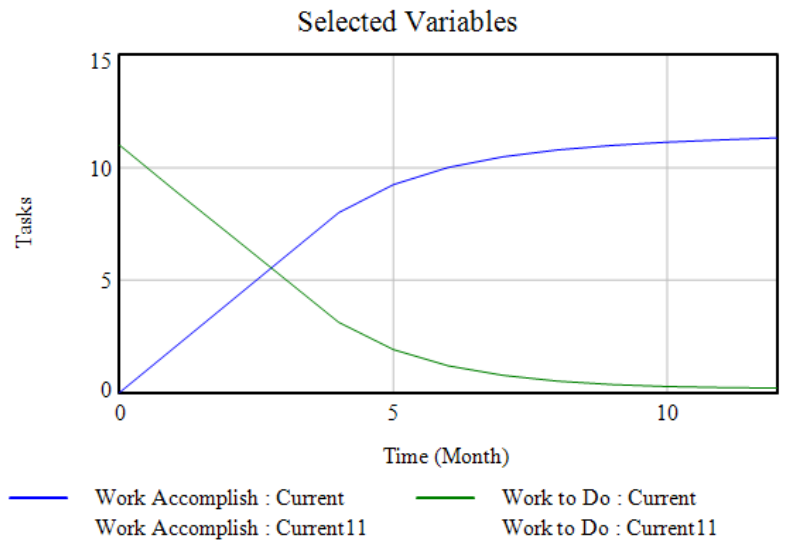

Figure (3) The Work Accomplish of Ideal Project

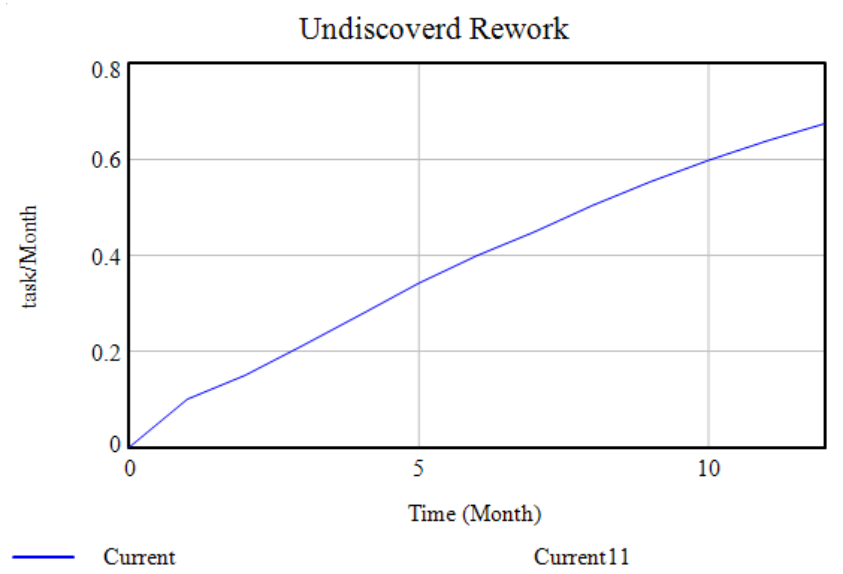

Figure (4) The Undiscovered Rework of Ideal Project

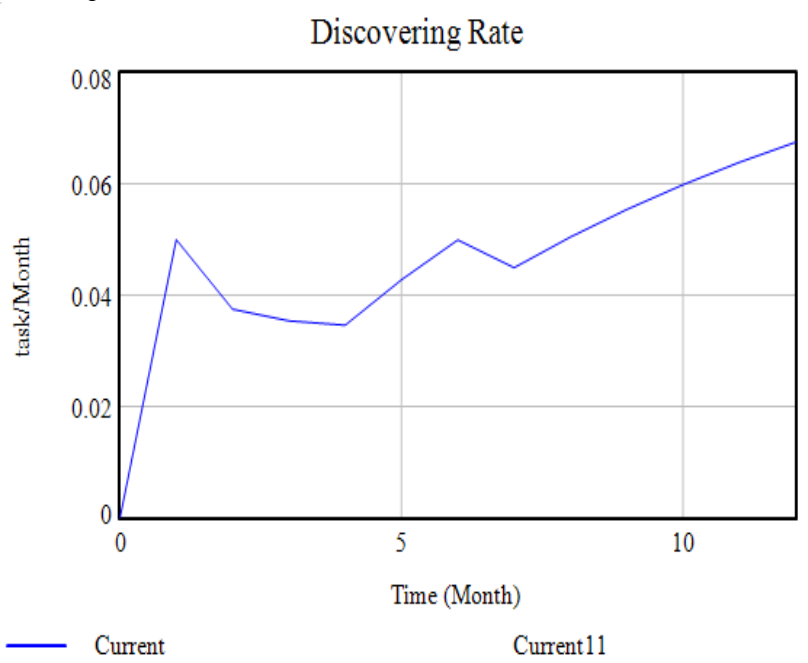

Figure (5) The Discovering Rate of Ideal Project

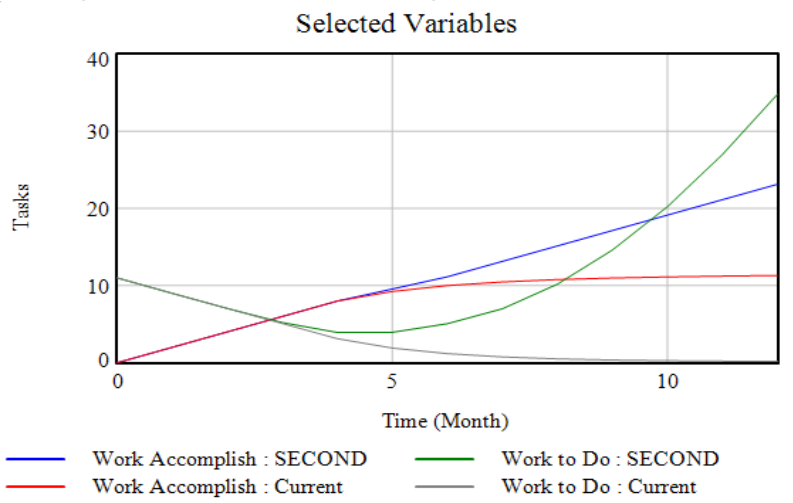

Figure (6) The Work Accomplish of Project with Problems 
Discovering Rate

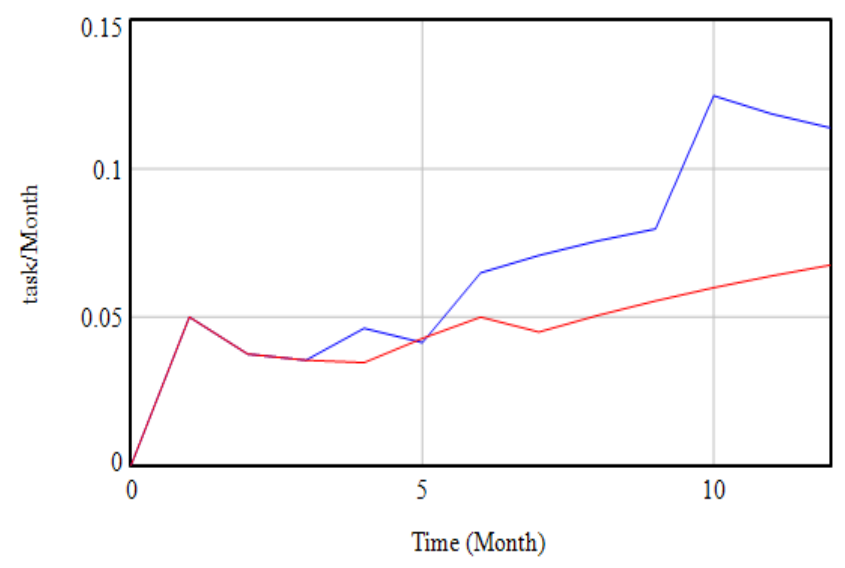

SECOND

Current

Figure (7) The Discovering Rate of Project with Problems

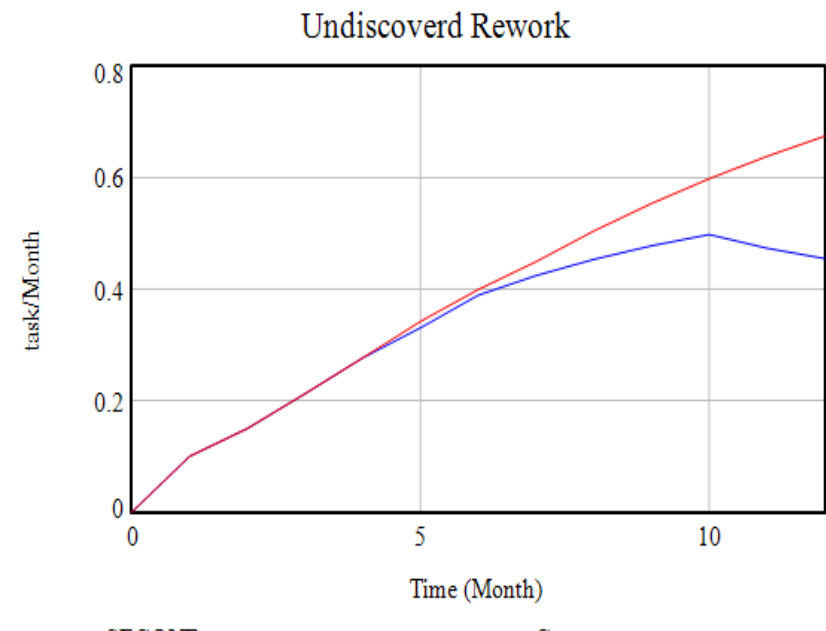

SECOND

Figure (8) The Undiscovered Rate of Project with Problems

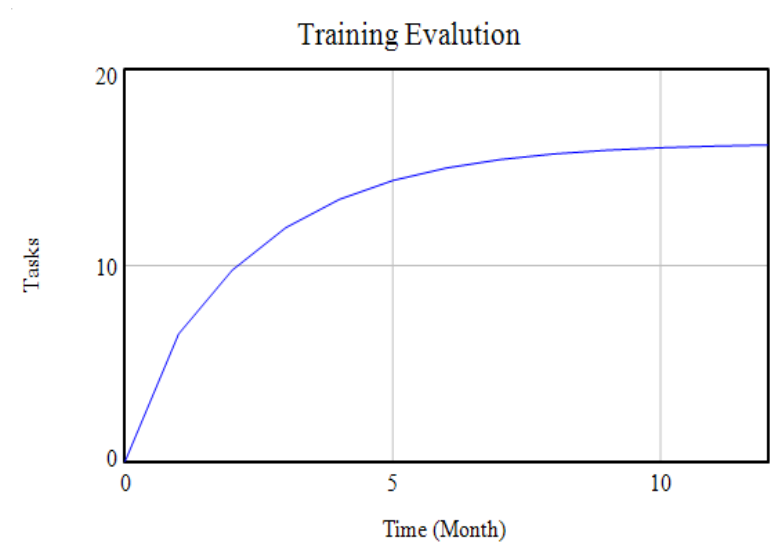

Figure (9) The Training Evaluation

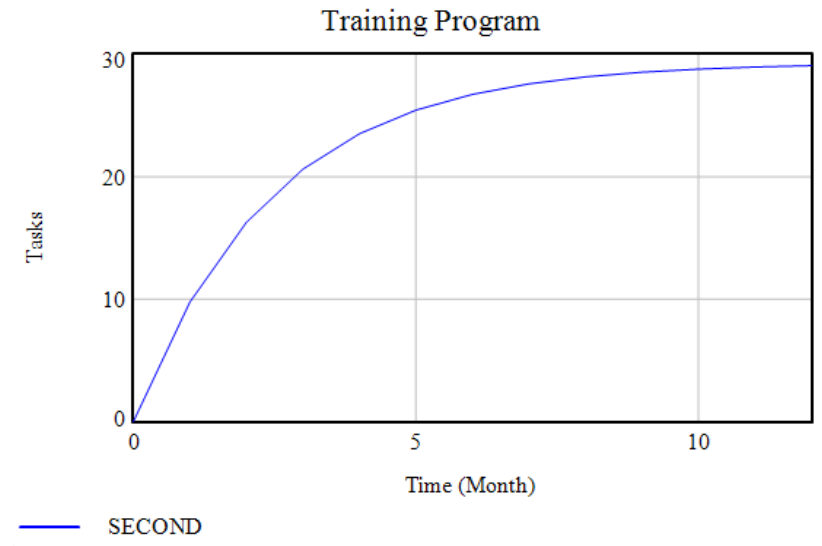

Figure (10) The Training Program Miss in Trianing

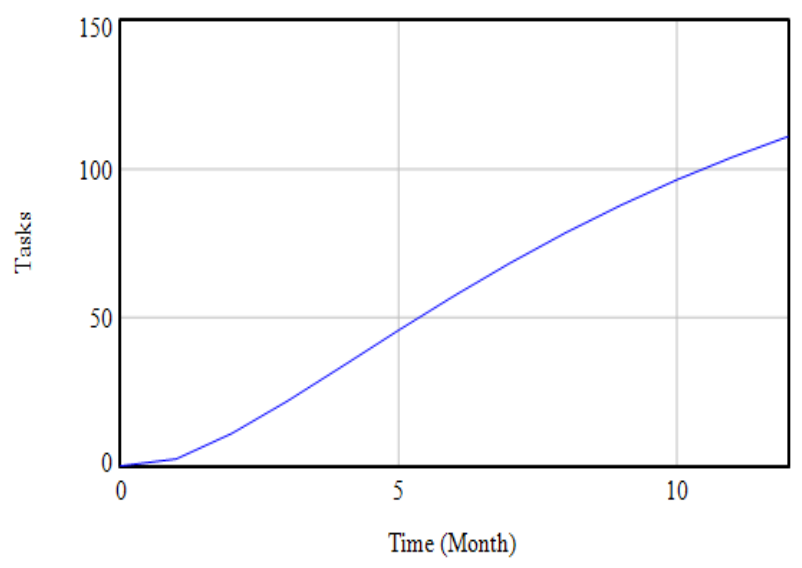

- SECOND

Figure (11) The Miss in Training Cost Overunse

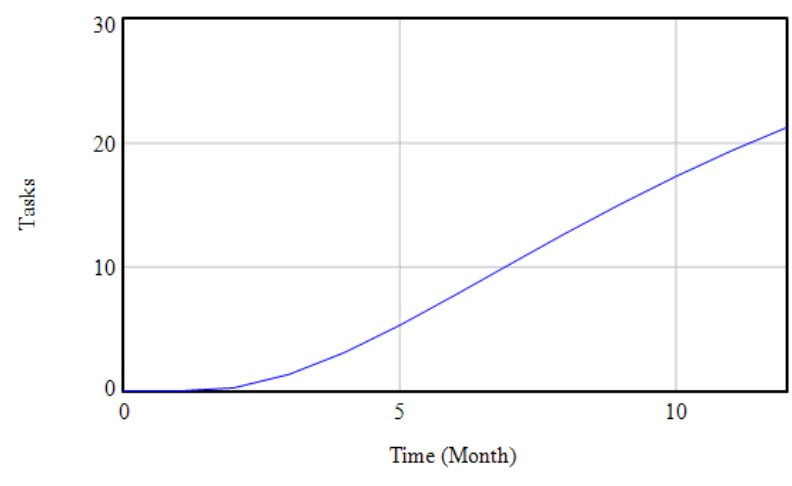

Figure (12) The Cost Overruns

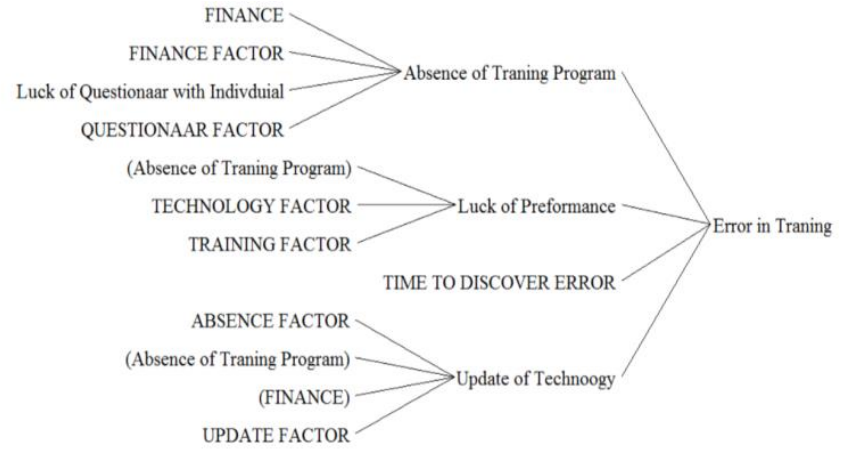

Figure (13) Cause Tree of Error in Training 


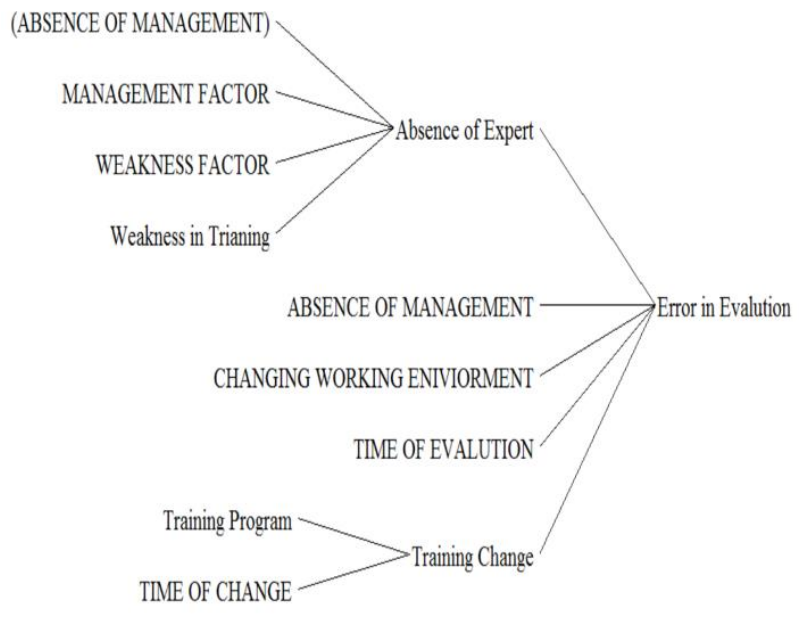

Figure (14) Cause Tree of Error in Evaluation

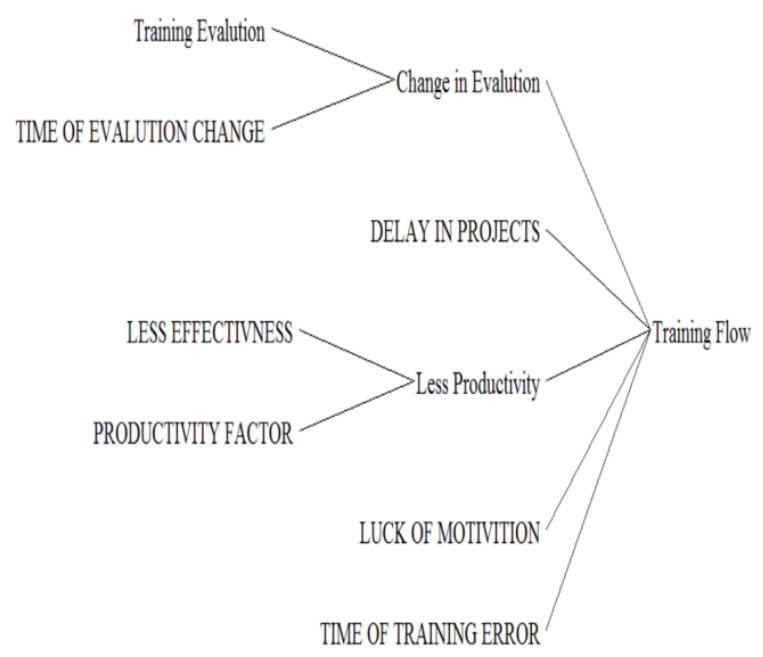

Figure (15) Cause Tree of Training Flow

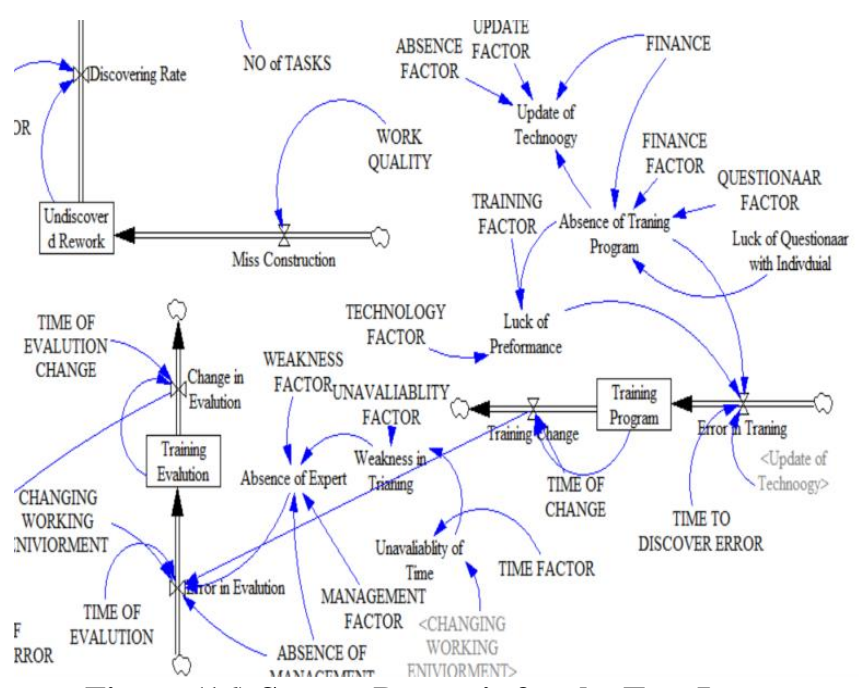

Figure (16) System Dynamic for the Two Items

Based on the results the authors made the following conclusions

1- The absence of training program has very strong effect as the absence of such program is caused by the finance absence, this is common problem with Iraqi construction industry. The most environment of the Iraqi industry is the absence of the finance from both owner and contractor as they ignore this part and consider unnecessary expenses and this will lead to unqualified engineering or worker in the wrong job

2- The absence of management mean that, usually the contractor and his staff are working without the supervise or represented from the owner side, which some time mean unskilled workers may be hired which lead to delay of the work and cost overruns

3- Both of the above will lead to error in the evolution of the training and hence increase in the cost, as of the employ a skilled worker and engineering they would not have to face this problem

4- In some case the training program is given, however it not given on the right time or to the right persons which result to waste of training and hence increased cost

5- The luck of time or absence in motivation , some consider important reason for the training.

6- One of the main cause that is not taken into consideration, the few experts that available in the field and that due to the system that used to select the employees and the engineering

\section{REFERENCES}

1- The number of construction firms in Great Britain reached its highest level on record (296,093 registrations).

2- ONS (2017) Construction Statistics. Number 182017 Edition, October

3- Hwang, B. and Ng, W. (2013). Project management knowledge and skills for green construction: Overcoming challenges. International Journal of Project Management 31 (2013). pp.272-284. Available at: http://www.nus.edu.sg/ dpr/files/research highlights/2013_10Oct_ProjectManagementKnowledge_Skills_green C onstruction.pdf (Accessed: 26 July 2014)

4- Drucker, P. F. (1998). The discipline of innovation. Leader to Leader, 1998(9), 13-15.

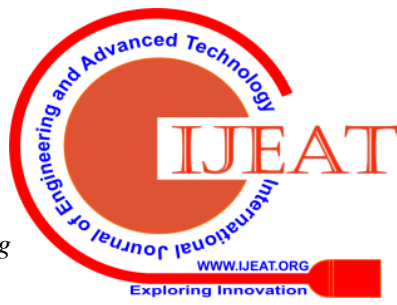


5- NIOSH (2010). Construction Safety. National Institute for Occupational Safety and Health (NIOSH), (available online http://www.cdc.gov/niosh/topics/constructionsafety,[assessed Jan 2010]

6- Hassan, F. , Mohd Fadhil Mohd, Masran, S., Zuhairusse Md-Derus, Takim, R. (2009). " A Framework for Designing Training for Construction Site Managers". Proceedings of the 3rd WSEAS International Conference on Energy Saving and Environmental Education, Tenerife, Spain.

7- Sambasivan, M. and Wen Soon, Y. (2007. Causes and Effects of Delays in the Malaysian Construction Industry, International Journal of Project Management, 25: 517-526.

8- Alwi, S; Hampson, K. and Mohamed, S. (2001). "Effect of Quality Supervision on Rework in the Indonesian Context." Asia Pacific Building and Construction Management Journal, 6 ( ) 2-6. 